ISSN 0258-7122 (Print), 2408-8293 (Online)

Bangladesh J. Agril. Res. 42(1): 27-34, March 2017

\title{
DEVELOPMENT OF COST EFFECTIVE SMALL NO-TILL SEEDER FOR TWO WHEEL TRACTOR IN BANGLADESH
}

\author{
MD. ISRAIL HOSSAIN ${ }^{1}$, M.K. GATHALA ${ }^{2}$, T.P. TIWARI ${ }^{3}$ \\ AND M. JAHEDUL ISLAM ${ }^{4}$
}

\begin{abstract}
Two wheel tractor (Power tiller) is the common means of soil tillage and other farm operations in Bangladesh due to easy access in fragmented land size with affordable price. A low cost and small robust 2WT driven (12 hp) No-till seeder has been developed with press wheel attachment and inclined plate seed meter assembly in Farm Machinery \& Postharvest Process Engineering Division, BARI, Bangladesh for seeding different kinds of seeds. This is a pull type implement hitched at drawbar point of $2 \mathrm{WT}$ replacing the regular rotary part. The developed No-till seeder was used in the farmer's field of Rajshahi areas for wheat, maize, pulses, and rice establishment during the year 2011-2014. The planter can pull 4 tynes in soft and medium hard soil but 3 tynes for hard soil. The planter was capable to apply seed and fertilizer in the furrows. The width and depth of the furrow opening were $30 \mathrm{~mm}$ and $60 \mathrm{~mm}$, respectively. The planting depth, row spacing and seed rate can be adjusted according to standard practices. The No-till seeder works effectively through high density crop residue (1.5-2.4 t/ha) without any problem as there are sufficient residue clearances between toolbar and ground surface. Depending on the level of weed situation, round up herbicide was applied 2 days before of planting. There were significant yield difference in wheat, pulses but rice yield was lower than conventional transplanting method. No-till planted crops show less lodging tendency compare to conventional planted crops. There were significant cost differences between no-till and conventional method. The planting costs of wheat and maize in Notill system were $60 \%$ and $86 \%$ less than conventional planting method. It also reduces the average turn around time 7-9 days between the two crops. The effective area coverage by the seeder was $0.13 \mathrm{ha} / \mathrm{hr}$. The No-till seeder is a low cost (US\$ 350-400; without power unit), light in weight and local manufacturer can fabricate complete unit within a short period of time. The No-till seeder can be used in other countries where $2 \mathrm{WT}$ is the common farming equipment.
\end{abstract}

Keywords: Two wheel tractor, No-till seeder, residue clearance, turn around time, inclined plate seed meter, tyne opener.

\section{Introduction}

Conservation agriculture (CA) based two wheel tractor (2WT) operated seeding implements are becoming popular among the farmers in Bangladesh. Zero tillage

${ }^{1}$ Chief Scientific Officer, FMP Engineering Division, Bangladesh Agricultural Research Institute (BARI), Gazipur, ${ }^{2 \& 3}$ Cropping Systems Agronomist, CIMMYT Bangladesh, Dhaka and ${ }^{4}$ Scientific Officer, On Farm Research Division, BARI, Rajshahi, Bangladesh. 
can overcome late planting which is a major problem in most wheat producing areas and it reduces the yield and efficiency of applied inputs to the crop. A linear decline in yield of $1-1.5 \%$ per day is observed when wheat is planted after the end of November irrespective of the maturity duration of the varieties. In this case increased nitrogen applications can not compensate for the decline in yield from late planting (Saunders,1988). The area under zero tillage in Indian subcontinent has been increased tremendously since last decades or so, which was estimated to be more than 5.61 lakh ha in 2002-03 with about 1.07 lakh farmers. Zero till minimizes the need for the number of tillage operations, reduces planting time and saves fuel and labour costs in both timely planting and late planting situations. It is reported that yield grains due to zero till planting are more in areas where late planting is a common feature as compared to timely sown areas (Gupta et al, 2003). In no-till farming the soil is left intact and crop residue is left on the field. Tilling a field reduces the amount of water, via evaporation around $1 / 3$ to $3 / 4$ inches $(0.85$ to $1.9 \mathrm{~cm})$ per pass. By no-tilling, this water stays in the soil, available to the plants (Wikipedia, 2010). According to the latest estimates, the number of $2 \mathrm{WT}$ are 700,000 operating in the country (Mondal, 2013).

In Bangladesh, No-till seeder of 2WT was first developed in WRC, BARI with FAO-CIMMYT supported programme (2003-04). This seeder had no press wheel and limitation to bold size seeds sowing. The No-till seeder was improved with ACIAR support with the introduction of lighter weight toolbar frame, press wheel attachment, seed and fertilizer box fixing over the handle bar of a tractor for free flow of seeds to ground (Hossain et al., 2009). This seeder performed better through crop residue but operators were still not satisfied due to the height of seed box which blocked the forward view of the field being seeded. Therefore, a user-friendly, small 2WT No-till seeder was developed capable of handling most seeds and managing crop residue properly.

Objectives: The specific objectives of this study are

i) To develop a cost effective No-till seeder for better establishment of crops

ii) To demonstrate the No-till seeder in the farmer's field; and

iii) To compare the cost of planting of the seeder over conventional method

\section{Materials and method}

Two wheel tractor (2WT) operated No-till seeder is a pull type seeder and it has been developed in Farm Machinery \& Postharvest Process Engineering Division, 
BARI, Bangladesh. The major components of the seeder are hitch plate, toolbar frame, seed and fertilizer box, with improved " $T$ " furrow opener, press wheel and chain-sprocket power transmission. The toolbar frame facilitates fittings different types of seed metering devices (Inclined plate seed meter, flute type and cup feed type seed meter as required), furrow openers, seed box. The No-till seeder has been improved with locally available materials such as M.S. angle, stainless steel bar, M.S sheet, ball bearing etc (Fig.1). All accessories were set up under the handle bar of

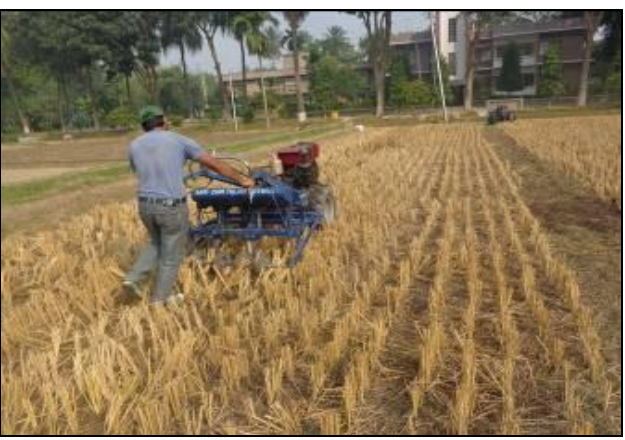

Fig. 1. 2WT operated no till seeder the $2 \mathrm{WT}$, which was not the case in earlier versions. Field performances and adaptive trials of the seeder were conducted in the farmers' field, by attaching a 12 hp Chinese Dongfeng 2WT. In North West drought prone area during 201114; wheat, mungbean, chickpea, maize and rice were successfully established using this seeder. The specification of the No-till seeder is shown in Table 1.

Table 1. Specification of 2WT operated No-till seeder and accessories

\begin{tabular}{|c|c|c|c|}
\hline S.N. & Items of No-till seeder & Specification & Remarks \\
\hline 1 & Power & $12 \mathrm{hp}, 2 \mathrm{WT}$; one operator & Dongfeng type, China \\
\hline 2 & Hitch plate & 120 x $150 \mathrm{~mm}$; Steel plate & Clump and lock pin used \\
\hline 3 & Toolbar frame & $\begin{array}{l}800 \times 1120 \mathrm{~mm} ; 3 \text { bar; } 50 \mathrm{~mm} \\
\text { Sq stainless steel }\end{array}$ & $\begin{array}{l}\text { Middle bar position } \\
\text { adjustable }\end{array}$ \\
\hline 4 & Seed \& fertilizer box & $\begin{array}{l}800 \times 330 \mathrm{~mm} ; 22 \text { gauge steel } \\
\text { plate }\end{array}$ & \\
\hline 5 & $\begin{array}{l}\text { Seed metering } \\
\text { mechanism }\end{array}$ & $\begin{array}{l}170 \mathrm{~mm} \text {, Inclined plate, variable } \\
\text { cell size }\end{array}$ & $\begin{array}{l}\text { Plate adjustable } 30^{\circ}-60^{\circ} \\
\text { position }\end{array}$ \\
\hline 6 & Furrow opener & $510 \times 70 \times 10$ mm“T” type; Steel & $\begin{array}{l}\text { Using used car leaf } \\
\text { spring }\end{array}$ \\
\hline 7 & Press wheel & 250-50 mm; rubber coated & Seeding row adjustable \\
\hline 8 & Power transmission & $\begin{array}{l}\text { Chain No. } 428 \text { with different } \\
\text { size sprocket }\end{array}$ & Power from wheel axel \\
\hline 9 & Depth control bar & $460 \times 10 \mathrm{~mm}$ steel bar & \\
\hline 10 & Over all dimension & $\begin{array}{l}2460 \times 1120 \text { x1200 mm } \\
\text { Weight: } 115 \mathrm{~kg} \text { (without engine) }\end{array}$ & Turning $1.5 \mathrm{~m}$ space \\
\hline
\end{tabular}


Wheat, maize, chickpea planted after rice harvest in the month of November and mungbean planted after wheat harvest in early April. The seeder used effectively in the rice and wheat residue condition (1.5 - $2.4 \mathrm{t} / \mathrm{ha}$ ) without any problem as there are sufficient clearance between toolbar and ground surface. The variety of wheat, maize and mungbean used for calibration and experimentation were Prodip, NK 40, BARI Mung-6, respectively. Di- Ammonium Phosphate (DAP) fertilizer $130 \mathrm{~kg} / \mathrm{ha}$ was applied along with the planting operation of wheat and maize in the farmer's field. Operation view of press wheel attached No-till drill was shown in Fig.2. The planting depth and seed covering mechanism were adjusted during the field operation. Before planting operation started Roundup herbicide was applied @ $100 \mathrm{ml}$ in 10 lit water for 5 decimal land irrespective of existing weeds. Field performances data of the seeder were recorded as per Regional Network of Agricultural Machinery (RNAM) Test Code. Fuel consumption, operation time, etc. were also collected to compare the cost saving over conventional method.

\section{Data collection}

The following data were collected - i) Depth of seed placement, $\mathrm{cm}$; ii) Travel speed, $\mathrm{km} / \mathrm{hr}$; iii) Effective field capacity, ha/hr ; iv) Field efficiency, \% ; v) Fuel consumption, $1 / \mathrm{hr}$; vi) No. of plants $/ \mathrm{m}^{2}$ and viii) Crop yield, $\mathrm{kg} / \mathrm{m}^{2}$. Cost was calculated according to the farm machinery utilization method (Anon., 1991; Hunt, 1995).

\section{Results and Discussions}

Field performance of the No-till seeder for wheat, maize, mungbean, chickpea establishment in several farmers field indicated that crops can be established immediate after rice harvest using residual soil moisture. There was enough ground clearance $(45 \mathrm{~cm})$ between soil surface and toolbar. Furrow openers lay out was jig-jag way, which facilitated passing crop residue without blocking. Row positions can be adjusted sliding the clump of tynes on the toolbar frame. Soil moisture monitoring during wheat planting period showed that No-till plot had higher moisture content for a longer period than conventional tilled plot (Fig.3). Effective field capacity of the seeder for wheat, maize and mungbean planting recorded $0.12 \mathrm{ha} / \mathrm{hr}, 0.14 \mathrm{ha} / \mathrm{hr}$, and 0.14 $\mathrm{ha} / \mathrm{hr}$, respectively. It was reported that the seeder with 4 tynes is more appropriate for soft to medium hard soil and 3 tynes for hard soils. The effective field capacity for maize planting found to be higher than wheat planting that was due to faster speed of operation (Table 2). Average fuel consumption of No-till seeder was $1.2 \mathrm{lit} / \mathrm{hr}$. The seeder was intensively used in the farmers' field for planting various crops. 


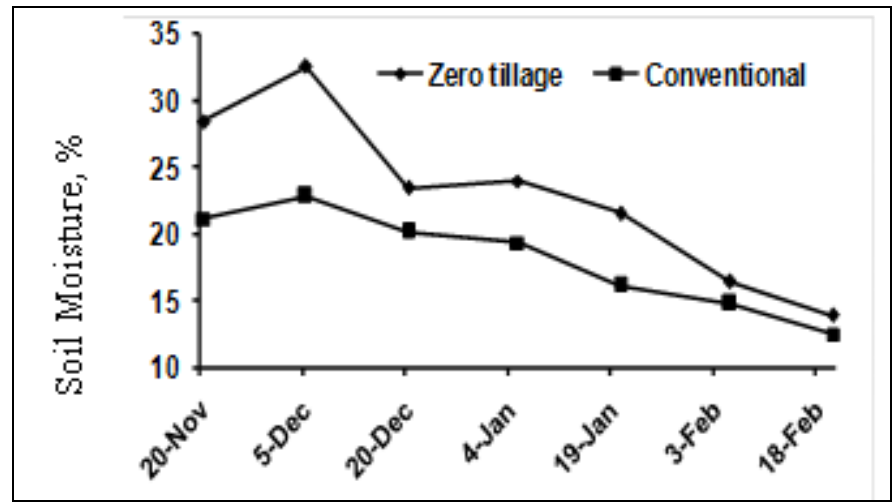

Fig. 3. Soil moisture change over the season.

Table 2. Field performance of 2WT operated no-till seeder

\begin{tabular}{l|l|c|c|c|c}
\hline S1 No & \multicolumn{1}{c|}{ Parameters } & Wheat & Maize & Mungbean & Chickpea \\
\hline 1 & Fuel consumption, lit./hr & 1.20 & 1.20 & 1.20 & 1.20 \\
2 & Speed of operation, km/hr & 2.50 & 2.70 & 2.70 & 2.50 \\
3 & Soil moisture content, $\%$ & 28 & 28 & 22 & 22 \\
4 & $\begin{array}{l}\text { Effective field capacity, } \\
\text { ha/hr }\end{array}$ & 0.12 & 0.14 & 0.14 & 0.12 \\
5 & Field efficiency, \% & 78 & 82 & 82 & 80 \\
\hline
\end{tabular}

Crop establishment by No-till seeder was shown in Table 3. Applied seed rate for wheat, maize, mungbean and chickpea were 120 $\mathrm{kg} / \mathrm{ha}, 20 \mathrm{~kg} / \mathrm{ha}$ and $23 \mathrm{~kg} / \mathrm{ha}, 35$ $\mathrm{kg} / \mathrm{ha}$, respectively. Average planting accuracy of those seeds were $94 \%$ on the basis of desired seed spacing. The average width of soil opening slits by tyne was 2-3 $\mathrm{cm}$ and depth of planting $4-5 \mathrm{~cm}$, which was enough for most of the

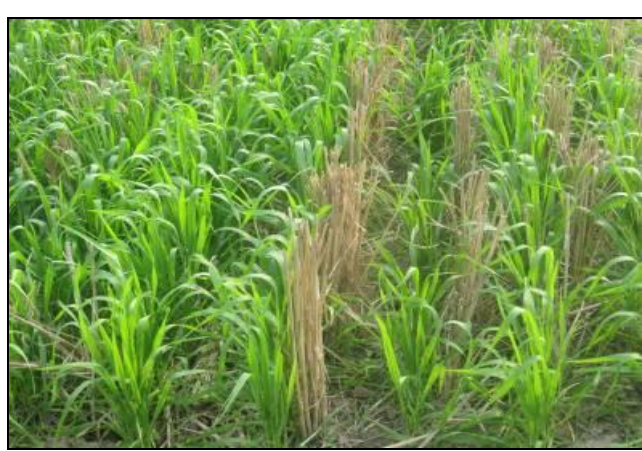

Fig. 4. No till planted wheat field

crops. It was found that slower speed was comparatively better for seed placement into the opening slit for all crops. No-till wheat plant establishment plot was shown in Fig.4. The adjustment of row spacing between two successive pass was maintained by an experienced and skilled operator. The width of slit during maize sowing was bigger due to the slightly dipper position of the " $\mathrm{T}$ " opener. Maize planting was more accurate with inclined plate seed meter. 
Table 3. Crops establishment by No-till seeder

\begin{tabular}{c|l|c|c|c|c}
\hline S1 No & \multicolumn{1}{c|}{ Parameter } & Wheat & Maize & Mungbean & Chickpea \\
\hline 1 & Variety & Prodip & NK 40 & BARI Mug-6 & BARI Sola 9 \\
2 & Seed rate (kg/ha) & 120 & 20 & 23 & 35 \\
3 & Row to rows spacing (cm) & 20 & 60 & 30 & 40 \\
4 & Average seed to seed distance & 1 & 20 & 5 & $8-10$ \\
& (cm) & & & & \\
5 & Number of rows per pass & 4 & 2 & 3 & 3 \\
6 & Depth of planting (cm) & 4 & 5 & 4 & 5 \\
7 & Plant population (m $\left.{ }^{2}\right)$ & 198 & 9 & 34 & 32 \\
8 & Width of soil opening slits (cm) & $2-3$ & $2.5-3.0$ & $2-3$ & 3 \\
9 & Planting uniformity (\%) & 85 & 95 & 88 & 94 \\
\hline
\end{tabular}

It was observed from Table 4 that there were variations of plant population using press wheel and without press wheel in No-till seeder. Press wheel covered the seeding lines, which ensured seed-soil contact properly. Initial wheat plant population per meter square of with press wheel and without pressed wheel were 235,205 , respectively. Without press wheel seeded plot; direct sunlight exposed on seeds \& open furrow, moisture loss, bird damage the seeds which resulted average $15-20 \%$ less population in wheat seeding. Similarly, in maize, mungbean and chickpea plots. Press wheel also facilitates seeder transportation from place to place.

Table 4. Effect of plant stand on press wheel (+) and without press wheel (-) by Notill seeder

\begin{tabular}{|c|c|c|c|c|c|c|c|}
\hline \multirow[b]{2}{*}{ Sl No. } & \multirow[b]{2}{*}{$\begin{array}{l}\text { Name of } \\
\text { crop }\end{array}$} & \multirow{2}{*}{$\begin{array}{c}\text { Seed } \\
\text { germination } \\
(\%)\end{array}$} & \multicolumn{2}{|c|}{ Seeding depth, mm } & \multicolumn{3}{|c|}{ Plant population $/ \mathrm{m}^{2}$} \\
\hline & & & $\begin{array}{c}\text { (+) Press } \\
\text { wheel }\end{array}$ & $\begin{array}{l}\text { (-) Press } \\
\text { wheel }\end{array}$ & $\begin{array}{c}\text { (+) Press } \\
\text { wheel }\end{array}$ & $\begin{array}{c}\text { (-) Press } \\
\text { wheel }\end{array}$ & $\%$ increase \\
\hline 1 & Wheat & 97 & 40 & $36-40$ & 235 & 205 & 15 \\
\hline 2 & Maize & 94 & 50 & $45-47$ & 12 & 10 & 20 \\
\hline 3 & Mungbea & 88 & 40 & 40 & 33 & 28 & 17 \\
\hline 4 & Chickpea & 96 & 50 & 48 & 40 & 32 & 25 \\
\hline
\end{tabular}

The yield of wheat, mungbean, rice, maize and chickpea in No-till and conventional method were presented in (Table 5). The wheat-mungbean-rice crop rotation continues last 4 years on station Rajshahi where the soil type is dominantly silty clay loam. Rice was seeded directly in unploughed/unpuddled soil. It was observed that there were significant yield variations between No-till and conventional method (Table 5). Wheat, mungbean, chickpea yields were comparatively higher than conventional method all the years. But rice and maize yield were slightly lower in No-till plots. Weed management in No-till rice cultivation is still challenging for convince traditional rice farmers. Weed management, herbicide availability, application techniques along with 
appropriate crop cultivar need to be more correct for disseminating the technology. Farmers reported that rice after mungbean plots required $30 \%$ less nitrogen fertilizer. There was a great potential to fit legume crop between ricewheat by no till planting system in rice-wheat cropping system reducing 7-9 days turn around time. It was also critically observed that No-till wheat, maize were less lodge compare to conventional planted wheat, maize even medium strong wind passes. It was due strong crop root anchor in soil compare to much loose soil in conventional tilled soil.

Table 5. Comparison of yield ( $t / h a)$ and planting cost between No-till and conventional planting method

\begin{tabular}{c|c|c|c|c|c|c|c|c|c|c}
\hline \multirow{2}{*}{ Year } & \multicolumn{2}{|c|}{ Wheat } & \multicolumn{2}{c|}{ Mungbean } & \multicolumn{2}{c|}{ Rice } & \multicolumn{2}{c|}{ Maize } & \multicolumn{2}{c}{ Chickpea } \\
\cline { 2 - 12 } & No till & Conv. & No till & Conv. & No till & Conv. & No till & Conv. & No till & Conv. \\
\hline 2011 & 3.6 & 3.3 & 0.9 & 0.8 & 3.4 & 3.5 & 8.3 & 8.7 & - & - \\
2012 & 3.7 & 3.3 & 1.0 & 0.8 & 3.5 & 3.7 & 8.2 & 8.4 & 1.8 & 1.2 \\
2013 & 3.7 & 3.4 & 1.1 & 0.9 & 3.63 & 3.6 & 8.6 & 8.7 & 2.1 & 1.2 \\
2014 & 3.9 & 3.5 & 1.2 & 0.9 & 3.72 & 4.0 & 8.8 & 8.9 & 1.7 & 1.1 \\
\hline CV (\%) & 3.5 & 3.9 & 2.3 & 2.3 & 5.75 & 5.5 & 10.6 & 7.8 & 6.7 & 5.3 \\
\hline LSD (0.05) & 0.12 & 0.11 & 0.11 & 0.12 & 0.119 & 0.11 & 0.26 & 0.23 & 0.23 & 0.19 \\
\hline $\begin{array}{c}\text { Cost of } \\
\text { planting }\end{array}$ & 2173 & 5437 & 2175 & 5437 & 2175 & 8675 & 1975 & 14500 & 2175 & 5437 \\
(Tk./ha) & & & & & & & & & & \\
\hline
\end{tabular}

Planting cost and break-even point used for No-till seeder was calculated on the basis of purchase price, fixed cost, variable cost, seeder life, depreciation cost, salvage value, bank interest rate, custom hire price and annual use of the seeder. Seeder price was Tk. 30,000.0 (US\$ 400) where planting cost of wheat, mungbean, rice and chickpea were Tk.2175.0/ha and maize only Tk. 1975.00/ha (Table 5). The planting costs of wheat and maize in No-till system were $60 \%$ and $86 \%$ less than that of conventional planting method. The planting cost variation was due to different effective field capacity of the seeder for different crops as row spacing of crops are different.

\section{Conclusions}

- The small $2 \mathrm{WT}(9 \mathrm{~kW})$ No-till seeder can pull 4 tynes in soft to medium hard soil but 3 tynes in hard soil.

- Interchangeable inclined plate seed metering device can handle efficiently most of the seeds sizes like wheat, maize, chickpea, rice and other pulses seeds.

- Yield of wheat, mungbean, rice, maize and chickpea was not reduced in No-till as compared to conventional method. 
- No-till seeder cost to be reduced for growing different crops substantially with reduction around time, so it can be made in local manufacturer.

- No-till seeder is low cost (US\$ 350-400; without power unit), lighter in weight and local manufacturer can fabricate complete set within a short period of time.

\section{Acknowledgments}

The authors are pleased to acknowledge International Maize and Wheat Improvement Centre (CIMMYT) and Australian Centre for International Agricultural Research (ACIAR) funded Sustainable and Resilient Farming System Intensification (SRFSI) project for financial and technical support to conduct the research works both on station and in the farmers' field. The authors express especial thanks to Mr Jeff Esdaile, Consultant, ACIAR project, NSW, Australia for the technical cooperation of small No-till seeder development.

\section{References}

Anonymous. 1991. Calculation Method of Farm Machinery Utilization. Farm Mechanization Planning (Mechanization Management), Vol.3; JICA, TIATC, Japan.

Gupta, R.K., Sammar Singh, R.K. Malik, Govindra Singh, R.S. Mehla, G. Sah, J. Tripathi, R. K. Sarma, P. R. Hobbs, J. K. Ladla and B. K.Singh. 2003. Zero tillage in Rice-Wheat Systems: Frequently asked questions. Technical Bulletin No.6, RiceWheat Consortium for the Indo-Gengetatic Plains, New Delhi, India.

Hossain, M. I, R. Jeff Esdaile, Richard Bell, Chris Holland, Enamul Haque, K. Sayre and M. Alam. 2009. Actual Challenges: Developing low cost no-till seeding technologies for heavy residues; Small-scale no-till seeders for two wheel tractors. Lead paper. Proceedings of $4^{\text {th }}$ World Congress on Conservation agriculture, New Delhi.

Hunt, D. 1995. Farm Power and Machinery Management. Cost Determination. $9^{\text {th }}$ Edition, Iowa State University Press, America.

Mondal, S. M A. 2013. Chief guest lecture. Workshop of the Agricultural engineering technology development and dissemination. Workshop held at Farm machinery division of BARI, Gazipur, 5 June 2013.

Saunders, D. A. 1988. Crop management research: Summary of results, 1983-88. Monograph No.5: Wheat Research Centre, Dinajpur, Bangladesh.

Wikipedia. 2010: No-till farming. From Wikipedia, the free encyclopedia. http://en. wikipedia. org /wiki/ No-till_farming. 